\title{
PENGARUH PRODUK WISATA DAN KEBIJAKAN HARGA TERHADAP MINAT
} KUNJUNGAN WISATAWAN

Kartika Dewi

ARS University, Bandung, Indonesia. Email: kartikadewi31294@gmail.com

\begin{tabular}{|c|}
\hline \\
Histori Artikel \\
Submitted: \\
1 September 2019 \\
Reviewed: \\
14 September 2019 \\
Accepted: \\
1 Oktober 2019 \\
Published: \\
15 November 2019 \\
\end{tabular}

Kata Kunci : Produk pariwisata, harga, minat wisatawan

\begin{abstract}
ABSTRAK
Tujuan dari penelitian ini adalah untuk mengetahui Pengaruh Produk Pariwisata dan Kebijakan Harga terhadap Minat Wisata di Taman Buah Mekarsari Bogor. Jenis penelitian ini adalah deskriptif-verifikatif, sedangkan teknik pengambilan sampel yang digunakan adalah pengambilan sampel secara indindental dengan 100 responden. Teknik analisis data yang digunakan adalah analisis regresi linier berganda. Dari hasil uji statistik, diketahui bahwa produk pariwisata berpengaruh positif dan signifikan terhadap minat wisatawan dan kebijakan harga juga berpengaruh positif dan signifikan terhadap minat wisata, selain itu produk pariwisata dan kebijakan penetapan harga pengaruhnya terhadap minat wisatawan di Taman Buah Mekarsari sebesar 68,8\%
\end{abstract}

\section{EFFECT OF TOURISM PRODUCTS AND PRICE POLICY ON INTERESTS OF TOURISTS VISIT}

\begin{abstract}
The purpose of this research is to know the Influence of Tourism Product and Pricing Policies to Tourist Interest in Taman Buah Mekarsari Bogor. This research is descriptive-verifikative type, while the sampling technique used is incindental sampling with 100 respondents. The technique of data analysis used is multiple linear regression analysis. From the statistical test result, it was known that tourism product positively and significantly effect to tourist interest and pricing policy also had positive and significant influence to tourist, besides tourism product and pricing policy influence to tourist interest in Taman Buah Mekarsari equal to $68.8 \%$.
\end{abstract}

Keywords: Tourism Product, Price, Tourist Interest.

\section{PENDAHULUAN}

Bogor yang merupakan salah satu kota di Jawa Barat yang terletak di selatan Kota DKI Jakarta, Kota Bogor sering dijuluki sebagai kota hujan selain itu dalam perkembangan perekonomian, masyarakat menitik beratkan pada jasa dengan mengoptimalkan pemanfaatan sumber daya yang ada, terbukti dengan beragam destinasi wisata dan potensi lainya yang dimiliki Kota Bogor. Hal tersebut juga diperkuat dengan tabel kunjungan wisata di kota bogor dari tahun 2012 sampai tahun 2016 yang menunjukan data tahun 2012-2013 mengalami peningkatan sebesar $79,2 \%$, pada tahun 2013-2014 mengalami peningkatan 
sebesar 28,6\%, tahun 2014-2015 mengalami peningkatan sebesar $9,9 \%$ dan pada tahun 2015-2016 mengalami peningkatan sebesar $10 \%$.Dapat disimpulkan Kota Bogor mengalami peningkatan kunjungan wisata setiap tahunnya walalupun tidak signifikan, ketidak signifikan tersebut diakibatkan persaingan destinasi wisata di seluruh kota di Indonesia dan salah satu faktor yang dapat mempengaruhi peningkatan kunjungan wisata setiap tahunnya di Kota Bogor yaitu beragamnya daya tarik wisata yang dimiliki Kota Bogor yang akan menjadikan minat wisatawan untuk berkunjung ke Bogor.

Salah satu destinasi wisata di Kota Bogor dengan ciri khas wisata agronya adalah Taman Buah Mekarsari Bogor dengan berlokasi di Jl. Raya Cileungsi-Jonggol, Kec.Cileungsi, Kab.Bogor, Jawa Barat, menawarkan wisata rekreasi dan edukasi yaitu berwisata buah. Berikut data kunjungan ke Taman Buah Mekarsari, dari tahun 2012 sampai dengan tahun 2017 :

Tabel 1

Rekapitulasi Pengunjung

Taman Buah Mekarsari Bogor

\begin{tabular}{ccc}
\hline Tahun & $\begin{array}{c}\text { Jumlah } \\
\text { Kunjungan }\end{array}$ & $\begin{array}{c}\text { Pertumbuhan } \\
(\%)\end{array}$ \\
\hline 2012 & 361.551 & \\
2013 & 136.237 & $-62,30 \%$ \\
2014 & 215.306 & $58 \%$ \\
2015 & 263.932 & $22.6 \%$ \\
2016 & 230.407 & $-12,7 \%$ \\
\hline
\end{tabular}

Darihasil table I.2 diatas, menunjukan bahwa setiap tahunnya mengalami ketidakstabilan pertumbuhan yang mengakibatkan penurunan, hal tersebut menjadi suatu pokok permasalahan dalam penelitian ini, penurunan minat kunjungan bisa diakibatkan oleh berbagai faktor salah satunya adalah faktor lingkungan iternal/kegiatan internal perusahaan yang digunakan sebagai strategi pemasaran, kegiatan tersebut yaitu bauran pemasaran.

Bauran pemasaran merupakan unsur pemasaran yang terdiri dari perencanaan produk, penetapan harga, program promosi, saluran distribusi. Berdasarkan hal tersebut maka dalam peneliti ini mengabil unsur produk dan harga sebagai variabel yang diteliti yaitu produk wisata dan kebijakan harga.

Beberapa ahli dalam industri jasa atau hospitality menyatakan bahwa semakin

berkembangnya kesadaran wisatawan terhadap nilai suatu produk, maka wisatawan menginginkan nilai untuk uang yang telah mereka bayarkan. Wisatawan mengenal istilah value for money di masa sekarang. Value for money adalah cara wisatawan untuk membandingkan jumlah uang yang dibayarkan dengan kualitas fasilitas dan pelayanan yang diperolehnya.

Berdasarkan hal tersebut dapat, membuktikan bahwa produk wisata merupakan hal yang berpengaruh dalam meningkatkan minat pengunjung Taman Buah Mekarsari Bogor, selain itu harga merupakan satu-satunya unsuryang terdapat dalam marketing mix yang menghasilkan pendapatan dan aspek penting dalam destinasi wisata.

Dari penjelasan di atas dapat di katakana bahwa produk wisata dan kebijakan harga mempunyai peranan yang sangat penting dalam keputusan berkunjung wisatawan yang mengunjungi suatu destinasi wisata dan yang dapat mempengaruhi minat wisatawan.

Berdasarkan penjelasan tersebut, maka penelitian ini bertujuan untuk mengetahui Produk Wisata di Taman Buah Mekarsari Bogor, Kebijakan Harga di Taman Buah Mekarsari Bogor, dan pengaruhnya terhadap Minat Kunjungan Wisatawan di Taman Buah Mekarsari Bogor.

\section{LITERATUR REVIEW}

Penelitian mengenai Produk Wisata terhadap Minat pernah dilakukan oleh (Guspriyadi, 2015)dengan judul Pengaruh Kualitas Pelayanan Dan Produk Wisata Terhadap Minat Berkunjung Ke Kebun Binatang Bandung, dan penelitian mengenai Kebijakan Harga pun pernah dilakukan oleh (Amalia., 2015)dengan judul Pengaruh Kebijakan Penetapan Harga dan Kualitas Pelayanan Terhadap Proses Keputusan 
Pembelian Konsumen Baraya Travel, Kemudian penelitian mengenai hubungan Produk Wisata dan Kebijakan Harga terhadap Minat Kunjungan pernah dilakukan oleh (Kamaludin, 2014)dengan judul Pengaruh Bauran Pemasaran Produk, Harga Dan Lokasi Terhadap Keputusan Menginap Tamu Di Hotel Inna Simpang Surabaya.

\section{Produk Wisata}

Produk Wisata menurut (Oka, 2008), adalah kumpulan dari berbagai macam produk yang dihasilkan oleh perusahaan yang diberi pelayanan secara langsung kepada wisatawan bila melakukan perjalanan wisata. Dimensi Produk Wisata menurut Suryadana, M. Liga., (2015) dapat ditinjau dengan konsep 3 plus yaitu terdiri dari Daya tarik wisata (Attractions), Fasilitas dan pelayanan wisata (Amenities), Kemudahan untuk mencapai destinasi wisata (Accessibility), dan Keramahtamahan (Hospitality). Daya tarik wisata dan fasilitas wisata juga terlah terbukti menjadi faktor utama yang sangat menentukan dalam membentuk pengalaman wisatawan yang memuaskan di destinasi alam atau ekowisata (Hermawan, H., Wijayanti, A., \& Nugroho, D. S, 2019).

\section{Kebijkan Harga}

Harga merupakan unsur bauran pemasaran yang sifatnya fleksibel dimana setiap saat dapat berubah menurut waktu dan tempatnya. Menurut (Fandy, 2011) menyebutkan bahwa "harga merupakan satusatunya unsur yang memberikan pemasukan atau pendapata bagi perusahaa".

\section{Sedangkan}

(Kotler,

mendefinisikan bahwa "Price the amount of money charged for a product or service, or the sum of the value that customers exchange for the benefits or having or using the product or service"

Dimensi Kebijakan Harga menurut (Koler, P., and Amstrong, 2012)adalah Kesesuain Harga (suitability price), Daftar Harga (price list), Potongan Harga (discounts), Harga yang dipersepsikan (price perception).

\section{Minat Wisatawan}

Minat menurut (Djaali., 2013), adalah rasa lebih suka atau rasa ketertarikan pada suatu hal atau aktifitas, tanpa ada yang menyuruh, sedangkan Wisatawan menurut (Kusumaningrum, 2009)adalah orang yang sedang tidak berkerja, atau sedang berlibur dan secara sukarela mengunjungi daerah lain untuk mendapat sesuatu yang lain.

Dimensi Minat $\quad$ Wisatawan
menurut(Kotler, Philip, 2009:179),
menjelaskan mengenai teori AIDA yang
terdiri dari Attention (Perhatian), Interest
(Ketertarikan), Desire (Keinginan), Action
(Tindakan).

\section{Hubungan Produk Wisata Dan Kebijakan Harga Terhadap Minat Wisatawan}

Dalam sebuah destinasi, terdapat berbagai macam sub elemen yang saling mendukung dan memiliki keterkaitan satu samalain sehingga membentuk suatu kesatuan destinasi yang memiliki nilai dan daya tarik terhadap para calon wisatawan yang datang.

Menurut (Koler, P., and Amstrong, 2012) mengemukakan bahwa "Bauran pemasaran adalah seperangkat alat pemasaran yang digunakan perusahaan untuk terus-menerus mencapai tujuan pemasarannya di pasar sasaran".Berdasarkan hal tersebut maka dapat diambil kesimpulan bahwa produk wisata memiliki keterkaitan atau hubungan dalam hal menarik minat wisatawan atau keinginan dalam mengunjungi objek wisata.

Dampak harga dalam sebuah produk terhadap pembelian memilih hubungan keterkaitanbahwa informasi harga diterima melalui indra penglihatan dan pendengaran. Dari Iformasi tersebut kemudian dipahami secara keseluruhan, yaitu informasi tersebut diterjemahkan dan dibuat bermakna, misalnya konsumen memahami makna dari simbol harga melalui apa yang dipelajari dan dialami sebelumnya (Danang Sunyoto, 2013). 
Berdasarkan penjelasan tersebut dapat disimpulkan bahwa harga yang terdapat pada produk wisata yang ditawarkan kepada wisatawan akan berpengaruh terhadap keinginan wisatawan dalam berkunjung ke destinasi wisata.

\section{METODE}

Metode penelitian yang digunakan dalam penelitian ini merupakan penelitian jenis deskriptif verifikatif dan lokasi penelitian yang dipilih adalah Taman Buah Mekarsari Bogor. Variabel pada penelitian ini adalah Produk Wisata, Kebijakan Harga dan Minat Wisatawan.Melalui penelitian deskriptif ini maka diperoleh hasil deskriptif tentang tanggapan responden mengenai Produk Wisata, Kebijakan Harga, dan Minat Kunjungan Wisatawan Taman Buah Mekarsari Bogor.

Sedangkan Melalui penelitian verifikatif ini maka penulis bertujuan untuk mengetahui pengaruh Produk Wisata, Kebijakan Harga dan Minat Kunjungan Wisatawan Taman Buah Mekarsari Bogor.

Berdasarkan jenis penelitiannya, yakni deskriptif verifikatif yang dilaksanakan melalui pengumpulan data lapangan, maka metode penelitian yang akan digunakan adalah metode explanatory survey.

Survey informasi didapat dari sebagian populasi (sample respondent) dan dikumpulkan langsung di tempat kejadian, dengan tujuan untuk mengetahui pendapat dari sebagian populasi terhadap objek yang diteliti.Populasi pada penelitin ini adalah wisatawan Taman Buah Mekarsari Bogor. Berkaitan dengan populasi tersebut maka penelitian ini mengambil dari jumlah wisatawan pada saat kuesioner akan di bagikan yaitu pada saat weekday dan weekend yaitu hari jumat dan sabtu.

Teknik pengambilan sampel yang digunakan adalah Accidental Sampling. Pengumpulan data dilakukan dengan menyebarkan kuesioner kepada wisatawan Taman Buah Mekarsari Bogor. Jumlah sampel sebanyak 100 responden wisatawan Taman Buah mekarsari Bogor.

\section{Instrumen Penelitian}

Instrumen penelitian digunakan untuk melakukan pengukuran dengan tujuan menghasilkan data kuantitatif yang akurat, efisien dan komunikatif, maka setiap instrumen harus memiliki skala. Berdasarkan variabel-variabel penelitian yang digunakan dan pemaparan sebelumnya yang menyatakan bahwa penelitian ini menggunakan kuesioner atau angket sebagai instrumen utama, maka dapat diketahui skala yang digunakan dalam penelitian ini adalah skala likert.

Setiap ukuran yang menggunakan skala ini mempunyai tingkatan dari sangat positif sampai sangat negatif, yang dapat diberi skor sebagai berikut:

Tabel 2

Rentang Skor Nilai alternatif

\begin{tabular}{clc}
\hline No & \multicolumn{1}{c}{ Jawaban } & Skor \\
\hline 1 & Sangat Setuju & 5 \\
2 & Setuju & 4 \\
3 & Cukup & 3 \\
4 & Tidak Setuju & 2 \\
5 & Sangat Tidak Setuju & 1 \\
\hline
\end{tabular}

Sumber: Sugiyono (2015)

\section{Teknik Pengumpulan Data}

Wawancara (Interview), adapun wawancara yang sudah di lakukan peneliti pada saat pelaksanaan peraktek kerja lapangan di Taman Buah Mekarsari Bogor pada awal agustus dan pihakyang di wawancara adalah pengunjung serta staff karyawan Taman Buah Mekarsari.

Observasi, lokasi yang digunakan untuk observasi yaitu Taman Buah Mekarsari Bogor yang sudah dilaksanakan pada saat peraktek kerja lapangan.

Kuesioner, dibagikan pada saat weekday dan weekend yaitu kepada 100 responden yang bertujuan untuk memperoleh tanggapan responden mengenai pengaruh produk wisata dan kebijakan harga terhadap minat wisatawan Taman Buah Mekarsari. 
Studi Kepustakaan, yang digunakan berhubungan dengan teori-teori yang ada kaitannya dengan masalah dan variabel yang diteliti yang terdiri dari produk wisata, kebijkan harga dan minat kunjungan wisatawan.

\section{Teknik Pengujian Data}

Suatu hasil penelitian dikatakan valid jika terdapat kesamaan diantara data yang terkumpul dengan data yang sesungguhnya terjadi, sedangkan hasil penelitian dikatakan realiabel jika terdapat kesamaan data dalam waktu yang berbeda.

\section{Validitas dan Reliabilitas}

Pengujian validitas dalam penelitian ini menggunakan korelasi rank spearman. Hasil uji validitas menunjukkan semua nilai $r$ hitung menunjukkan hasil perhitungan di atas 0.361 ( $r$ table). Hasil tersebut memberikan gambaran bahwa semua kuesioner yang digunakan dalam uji validitas tersebut, dapat dilanjutkan untuk pengambilan data berikutnya. Pengujian reliabilitas dalam penelitian ini dilakukan dengan menggunakan koefisien Cronbach Alpha. Hasil uji reliabilitas menunjukkan semua nilai $r$ hitung menunjukkan hasil perhitungan di atas 0.60 ( $r$ table) maka semua variabel dalam penelitian ini sudah reliable.

\section{Teknik Analisis Data}

Analisis data penelitian ini melewati tiga tahap, tahap pertama dan kedua yaitu menganalisis produk wisata dan kebijakan harga yang diberikan oleh Taman Buah Mekarsari Bogor kepada Wisatawan yang berkunjung, tahap ketiga mengukur seberapa pengaruh minat wisatawan Taman Buah Mekarsari Bogor.

\section{Gambaran Umum Perusahaan}

Taman Buah Mekarsari merupakan salah satu pusat pelestarian dan budidaya keanekaragaman hayati buah-buahan tropika terbesar, khususnya jenis buah-buahan unggul yang dikumpulkan dari seluruh daerah di Indonesia.
Dibangunnya Taman Buah Mekarsari berawal dari, kisah Bapak Soeharto yang lahir dan di besarkan oleh keluarga petani, di tengah pedesaan yang sebagian besar penduduk kaum tani, Bapak Soeharto selalu memberikan perhatian yang besar kepada masalah pertanian dan kaum tani dalam upaya untuk meningkatkan harkat dan martabat kaum tani.

Visi dari Taman Buah mekarsari adalah sebagai pusat Pelestarian dan Pengembangan Plasma Nutfah yang bermanfaat bagi kemajuan Pendidikan dan Ilmu Pengetahuan di bidang holtikultur, serta obyek Wisata Agro yang terkemuka di Asia. Misi dari Taman Buah mekarsari Bogor yaitu memperkuat Brand Association Mekarsari melalui penyempurnaan dan pengembangan produk, mencapai Laba dan Pertumbuhan perekonomian perusahaan dan karyawan Taman Buah Mekarsari.

Produk yang ditawarkan Taman Buah Mekarsari terdiri dari wisata kereta (kereta regular, green land tour, family tour), berbagai macam Wahana wisata, wisata outbound dengan berbagai permainannya, kemudian ada wahana penginapan (rumah pohon, the cabin, family camp)

\section{HASIL DAN PEMBAHASAN}

\section{Hasil Penelitian}

Hasil analisis daya deskriptif dari penelitian ini menunjukan bahwa dari 100 responden yang berjenis kelamin perempuan sebanyak $61 \%$ dan laki-laki sebanyak 39\% dengan responden usia pengunjung paling banyak yaitu usia produktif (25-56 Tahun) sebesar 52\% yang berdomisili di Bogor sebesar $48 \%$.

Pendidikan terakhir responden kebanyakan SMU/SMK sebesar $41 \%$ dan pekerjaan sebagian besar pegawai swasta dengan pendapatan responden paling banyak berkisar Rp 2.000.000-Rp4.000.000. Hasil penelitian ini juga menunjukan sebagian besar alasan utama responden mengunjungi dikarenakan tempat mudah dijangkau dan responden cukup sering (2-5 kali) berkunjung sebanyak $44 \%$. 


\section{Analisis Deskriptif Variabel Produk Wisata (X1)}

Dalam Variabel Produk Wisata, terdapat empat indikator yaitu: Attraction, Amenities, Accessibilities, dan Hospitality. Dalam indicator Attraction mengindikasikan bahwa wisata buah yang di miliki Taman Buah Mekarsari mengalami penurunan dalam menarik minat wisatawan, di karenakan tidak menentunya waktu panen tumbuhan di Taman Buah Mekarsari Bogor, untuk pilihan wahana wisata yang dimiliki Taman Buah Mekarsari sudak lengkap dan banyak pilihan wahana wisatanya dan wahana wisata yang di miliki Taman Buah Mekarsari Bogor selain berupa wahana rekreasi juga merupakan wahana edukatif yaitu segela kegiatan belajar mengenai tumbuhan

Indikator Amenities menjelaskan fasilitas yang di miliki Taman Buah Mekarsari Bogor sudah lengkap, yaitu dengan tersediannya pendopo, toilet portabel, tempat parkir yang luas, dan fasilitas lainnya, Wahana di Taman Buah Mekarsari Bogor sudah sesuai dengan standarisasi dan aman digunakan oleh wisatawan, karena semua wahana sebelum ditawarkan kepada wisatawan sudah di uji keamanannya oleh staf Mekarsari, Fasilitas yang di miliki Taman Buah Mekarsari sudah memenuhi kebutuhan wisatwan.

IndikatorAccessibility,mengindikasi

bahwa akses menuju Taman Buah Mekarsari Bogor sangat mudah dan di buktikan dengan banyaknya wisatawan yang datang dari luar bogor dan tersedianya transportasi umum menuju Taman Buah Mekarsari, dan Kondisi infastruktur jalan menuju Taman Buah Mekarsari Bogor masih kurang baik di karenakan jalan yang rusak dan sempit yang mengakibatkan seringnya terjadi kemacetan di jalur menuju Taman Buah Mekarsari Bogor.

Indikator Hospitality, mengindikasikan bahwa Taman Buah Mekarsari Bogor selalu memberikan pelayanan yang ramahtamah kepada wisatawan dan sejalan dengan pondasi Taman Buah Mekarsari dalam point spirit "Semangat kerja untuk mencapai omset dan citra", yang mempungi maksud bahwa staff Taman Buah Mekarsari harus bisa memberikan pelayanan sebaik mungkin kepada wisatawan dalam mengembangkan objek wisata tersebut

Pada variabel produk wisata dengan jumlah pertanyaan sebanyak 10 item dan jumlah responden sebanyak 100 responden, diperoleh skor total sebesar 3.808 dengan presentase $76,2 \%$. Berdasarkan, interval skor setiap variabel produk wisata sebesar 3.808 berada pada interval 3.400-4.200 dan termasuk ke dalam kategori "Baik. Artinya, produk wisata yang di miliki Taman Buah Mekarsari menurut responden sudah baik dan sesuai dengan keinginan wisatawan hal ini juga di buktikan dengan tingginya tanggapan responden terhadap banyaknya pilihan wahana wisata yang di miliki Taman Buah Mekarsari baik bersifat rekreasi maupun edukatif.

\section{Analisis Deskriptif Variabel Kebijakan Harga (X2)}

Dalam variabel kebijakan harga terdapat empat indikator yaitu: Kesesuaian harga, Daftar harga, Potongan harga dan Persepsi harga.Indikator Kesesuaian Harga, mengindikasikan bahwa harga di Taman Buah Mekarsari cukup sesuai dengan kualitas produk wisatanya dan harga di Taman Buah Mekarsari sudah sesuai dengan pelayanan yang diberikan oleh karyawan Taman Buah Mekarsari berdasarkan moto spirit karyawan Taman Buah Mekarsari Bogor yaitu "Semangat kerja untuk mencapai omset dan citra"

IndikatorDaftarHarga menganalisis bahwa Informasi mengenai harga yang ditawarkan Taman Buah Mekarsari sudah cukup lengkap dengan berbagai informasi berupa brosur, dan papan informasi harga dan pihak Taman Buah Mekarsari Bogor sudah memberikan informasi mengenai harga yang ditawarkan dengan jelas kepada para wisatawan yang dating

Indikator Potongan Harga, menganalisis bahwa wisatawan pernah merasakan mendapat potongan harga yang di berikan oleh Taman Buah Mekarsari pada saat event tertentu yaitu contohnya saat libur nasional dan Taman Buah Mekarsari jarang 
memberikan potongan harga pada saat ulang tahun Taman Buah Mekarsari Bogor oleh karena hal itu juga banyak wisatawan yang tidak mengetahui kapan perayaan ulang tahun Taman Buah Mekarsari

Indikator Persepsi Harga, menganalisis bahwa harga yang ditawarkan Taman Buah Mekarsari sudah cukup sesuai dengan keadaan harga objek wisata sejenis dan Harga yang ditawarkan oleh Taman Buah Mekarsari belum sesuai dengan citra destinasi dimata pengunjung

Pada variabel kebijakan harga dengan jumlah pertanyaan sebanyak 8 item dan jumlah responden sebanyak 100 responden, diperoleh skor total sebesar 2.899 dengan presentase $72,5 \%$. Berdasarkan interval skor di atas, skor total variabel kebijakan harga sebesar 2.899 berada pada interval 2.7203.360 dan termasuk ke dalam kategori "Baik". Artinya, kebijakan harga di Taman Buah Mekarsari sudah baik dimata responden dan sesuai dengan wisatawan.

\section{Analisis Deskriptif Variabel Minat Wisatawan (Y)}

Dalam variabel minat wisatawan terdapat empat indikator yaitu: Attention, Intersest, Desire, dan Action. Dalam Indikator Attentionmengindikasikan bahwa wisata atraksi yang dimiliki Taman Buah Mekarsari Bogor diharapkan dapat lebih dikembangkan lagi supaya lebih menarik minat wisatawan dan sebagian besar wisatawan datang ke Taman Buah Mekarsari Bogor karena ingin mengetahui mengenai wisata buahnya

Indikator Interest, mengindikasikan bahwa banyak wisatawan yang datang ke Taman Buah Mekarsari Bogor karena suasana alamnya yang indah dan sejuk, dan sebagian kecil wisatawan beranggapan harga yang di tawarkan Taman Buah Mekarsari Bogor masih mahal dan tidak terjangkau bagai masyarakat menengah kebawah, walaupun segmentasi Taman Buah Mekarsari adalah kalangan menengah keatas, tidak dipungkiri di kalangan menengah kebawah pun daya tariknya cukup tinggi.
Indikator Desire, mengindikasikan bahwa wisatwan yang datang ke Taman Buah Mekarsari Bogor kebanyakan kerena kemauan sendiri dan wisatawan yang datang karena informasi wisatawan lain maupun dari berbagai media sosial mengenai objek wisata Taman Buah Mekarsari Bogor.

Indikator Action, mengindikasikan bahwa wisatawan yang berkunjung ke Taman Buah Mekarsari Bogor untuk berlibur dan rekreasi, dan wisatawan berpendapat bahwa tidak beragamnya buah-buahan yang tumbuh akibat kondisi dan cuaca yang tidak menentu atau musiman

Pada variabel minat wisatawan dengan jumlah pertanyaan sebanyak 8 tem dan jumlah responden sebanyak 100 responden, diperoleh skor total sebesar 3.107 dengan presentase $77,7 \%$. Berdasarkan interval skor di atas, skor total variabel minat wisatawan sebesar 3.107 berada pada interval 2.7203.360 dan termasuk ke dalam kategori "Baik".

\section{Uji Normalitas}

Normalitas dalam penelitian ini dapat diketahui dengan membandingkan nilai Asymp Sig. dengan nilai signifikansi $\alpha(0,05)$ pada hasil perhitungan statistik oleh software SPSS 16 for Windows. Hasil uji normalitas menunjukan bahwa nilai Asymp Sig. dari masing-masing variable >(lebih dari) signifikansi $\alpha(0,05)$. Dengan demikian, dapat disimpulkan bahwa data berdistribusi normal.

\section{Uji Multikolinieritas}

Multikolinieritas dalam penelitian ini dapat diketahui dengan melihat nilai VIF (Variance Inflation Factor) dan tolerance dimana VIF $<10$ dan tolerance $>0,10$ pada hasil perhitungan statistik oleh software SPSS 16 for Windows. Hasil uji multikolinieritas menunjukan bahwa nilai tolerance $=0,779$. Artinya, tolerance $>0,10$. Sedangkan, VIF $=1.284$. Artinya, VIF $<10$. Dengan demikian, dapat disimpulkan bahwa tidak terdapat multikolinieritas pada model ini. 


\section{Uji Heteroskedastisitas}

Heteroskedastisitas dalam penelitian ini dapat diketahui dengan melihat grafik scatterplot pada hasil perhitungan statistik oleh software SPSS 16 for Windows. Hasil uji heteroskedastisitas menunjukan bahwa model bersifat homoskedastik, yaitu tidak ada titik yang membentuk pola-pola tertentu secara teratur, melainkan menyebar secara acak, baik di atas maupun di bawah angka 0 pada sumbu Y. Dengan demikian, dapat disimpulkan bahwa tidak terjadi heteroskedastisitas pada model ini. Artinya, peningkatan nilai variabel independen (produk wisata dan kebijakan harga) pada sumbu $\mathrm{X}$ diikuti oleh peningkatan nilai residual.

\section{Uji Autokorelasi}

Autokorelasi dalam penelitian ini dapat diketahui dengan melihat nilai DW (DurbinWatson) pada hasil perhitungan statistik oleh software SPSS 16 for Windows. Hasil uji autokorelasi menunjukan bahwa nilai Durbin Watson $=1,984<2$. Dengan demikian, dapat disimpulkan bahwa tidak terdapat autokorelasi pada model ini.

\section{Uji Linieritas}

Heteroskedastisitas dalam penelitian ini dapat diketahui dengan melihat grafik Normal P-P plot of Regression Standardized Residual pada hasil perhitungan statistik oleh software SPSS 16 for Windows. Hasil uji linieritas menunjukan bahwa data menyebar di sekitar garis diagonal dan mengikuti arah garis diagonal atau grafik histrogramnya. Dengan demikian, dapat disimpulkan bahwa model bersifat linier.

\section{Analisis Koefisien Regresi Linear Berganda}

Analisis regrensi dilakukan untuk membuktikan hipotesis yang diajukan dalam penelitian ini, yakni untuk menganalisis hubungan antara variabel bebas (produk wisata dan kebijakan harga) dengan variabel terikat (minat wisatawan). Model persamaan regresi yang dapat dituliskan dari hasil uji regresi berganda dan dalam persamaan regresi bentuk standard adalah sebagai berikut:

$$
\begin{gathered}
\mathrm{Y}=\mathrm{b} 0+\mathrm{b} 1 \mathrm{X} 1+\mathrm{b} 2 \mathrm{X} 2 \\
\mathrm{Y}=3,204+0,275 x_{1}+0,663 x_{2}
\end{gathered}
$$

Koefesien regresi variabel produk wisata berpengaruh positif terhadap minat wisatawan. Koefesien regresi untuk $\mathrm{X}_{1}$ sebesar 0,275 dan bertanda positif dengan signifikansi 0,000. Hal ini berarti bahwa setiap peningkatan perubahan nilai produk wisata akan memberikan peningkatan skor sebesar 0,275.

Koefesien regresi variabel kebijakan harga berpengaruh positif terhadap minat wisatawan. Koefesien regresi untuk $\mathrm{X}_{2}$ sebesar 0,663 dan bertanda positif dengan signifikansi 0,000. Hal ini berartti bahwa setiap peningkatan perubahan nilai kebijakan harga akan memberikan peningkatan skor sebesar 0,663. Berdasarkan persamaan dan keterangan diatas dapat diketahui bahwa variabel bebas yang paling berpengaruh terhadap variabel terikat adalah variabel kebijakan harga sebesar 0,663. Lalu diikuti oleh variabel produk wisata sebesar 0,275.

\section{Analisis Koefisien Determinasi $\left(\mathbf{R}^{\mathbf{2}}\right)$}

Koefisien determinasi pada penelitian ini dapat diketahui dengan melihat nilai $R$ square pada hasil perhitungan statistik untuk mengetahui pengaruh variabel independen terhadap variabel dependen yang dilakukan menggunakan software SPSS 16 for Windows seperti yang ditunjukan pada tabel dibawah ini: 
Tabel 2

Hasil Uji Koefesien Determinasi $\left(\mathrm{R}^{2}\right)$

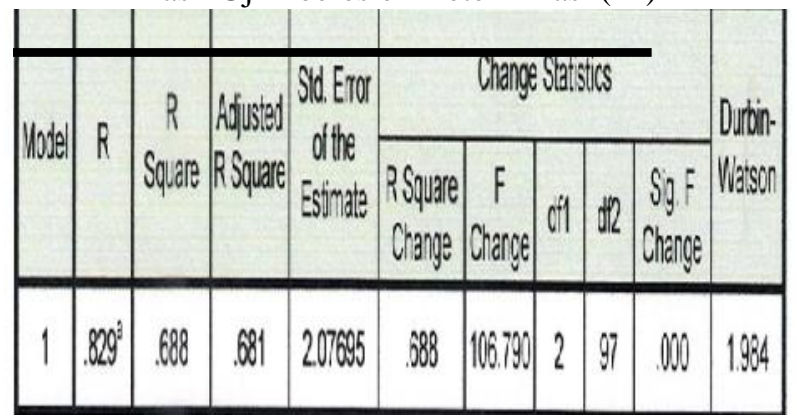

\section{Hasil Uji Koefisien Determinasi $\left(\mathbf{R}^{2}\right)$.}

Dari tabel 2 diatas, dapat dilihat bahwa nilai $\mathrm{R}$ square $=0,688$. Hal ini mengindikasikan bahwa produk wisata dan kebijakan harga berpengaruh terhadap minat wisatawan di Taman Buah Mekarsari Bogor, sebesar $68,8 \%$, sedangkan sisanya, yaitu $31,2 \%$ dipengaruhi oleh variabel-variabel lain yang tidak diteliti dalam penelitian ini.

\section{Uji Parsial (Uji T)}

Uji parsial pada penelitian ini dapat diketahui dengan melihat nilai ( $\mathrm{T}$ ) pada hasil perhitungan statistik oleh software SPSS 16 for Windows, seperti yang ditunjukan pada tabel berikut ini:

Tabel 3

Hasil Uji Parsial (Uji T)

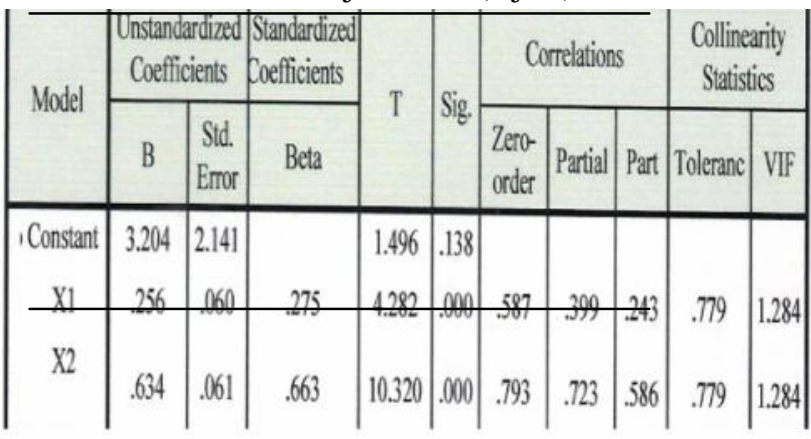

Dari tabel tersebut, dapat dilihat bahwa nilai t hitung $=4,282$ dan signifikansi hitung $=0,000$. Dengan menggunakan signifikansi $\alpha$ $(0,05)$ dan derajat kebebasan (df) n-k-1 atau $100-2-1=97(n=$ jumlah responden dan $\mathrm{k}=$ jumlah variabel independen), diperoleh $t$ tabel sebesar 1,66071. Artinya, t hitung $>\mathrm{t}$ tabel dan signifikansi hitung $<\alpha$.

Dengan demikian, $\mathrm{H}_{0}$ ditolak dan $\mathrm{H}_{\mathrm{a}}$ diterima dengan keterangan sebagai berikut:

1) $\mathrm{H}_{0}: \mathrm{pyx}_{1}=0$ ProdukWisata tidak berpengaruh signifikan terhadap minat wisatawan secara parsial.

2) $\mathrm{H}_{\mathrm{a}}: \rho \mathrm{yx}_{1}$ \#) Produk Wisata berpengaruh signifikan terhadap minat wisatawan secara parsial.

\section{Pengaruh Kebijakan Harga Terhadap Minat Wisatawan Secara Parsial.}

Dari tabel tersebut, dapat dilihat bahwa nilai $\mathrm{t}$ hitung $=10,320$ dan signifikansi hitung $=$ 0,000 . Dengan menggunakan batas signifikansi $\alpha(0,05)$ dan derajat kebebasan (df) $n-k-1$ atau $100-2-1=97$ ( $n=$ jumlah respondendan $\mathrm{k}=$ jumlah variabel independen), diperoleh $\mathrm{t}$ tabel sebesar 1,66071. Artinya, $\mathrm{t}$ hitung $>\mathrm{t}$ tabel dan signifikansi hitung <. $\alpha$. Dengan demikian, $\mathrm{H}_{0}$ ditolak dan $\mathrm{H}_{\mathrm{a}}$ diterima dengan keterangan sebagai berikut:

1) $\mathrm{H}_{0}: \rho \mathrm{y}_{2}=0 \quad$ Kebijakan harga tidak berpengaruh signifikan terhadap minat wisatawan secara parsial.

2) $\mathrm{H}_{\mathrm{a}}: \rho \mathrm{yx}_{2} \nRightarrow \quad$ Kebijakan harga berpengaruh signifikan terhadap minat wisatawan secara parsial.

\section{Uji Simultan (Uji F)}

Uji simultan (Uji F) pada penelitian ini dapat diketahui dengan melihat nilai $\mathrm{F}$ pada hasil perhitungan statistik oleh software SPSS 16 for Windows, seperti yang ditunjukan pada tabel dibawah ini:

Tabel 4

Hasil Uji Simultan (Uji F)

\begin{tabular}{|l|r|r|r|r|r|}
\hline \multicolumn{1}{|c|}{ Model } & Sum of Squares & $d f$ & Mean Square & $F$ & Sig. \\
\hline 1 Regression & 921.329 & 2 & 460.664 & 106.790 & $.000^{\circ}$ \\
Residual & 418.431 & 97 & 4.314 & & \\
Total & 1339.760 & 99 & & & \\
\hline
\end{tabular}

Dari tabel 4 tersebut, dapat dilihat bahwa nilai $F$ hitung $=106.790$ signifikansi hitung $=0,000$. Dengan menggunakan batas signifikansi $\alpha(0,05)$, diperoleh $F$ tabel sebesar 3,09. Artinya, F hitung $>\mathrm{F}$ tabel dan signifikansi hitung $<\alpha$.

Berdasarkan hasil uji parsial (uji F) di atas, dapat disimpulkan bahwa $\mathrm{H}_{0}$ ditolak, 
sementara $\mathrm{H}_{\mathrm{a}}$ diterima dengan keterangan sebagai berikut:

$\mathrm{H}_{0}$ : Produk Wisata dan Kebijakan Harga tidak berpengaruh signifikan terhadap Minat Wisatawan secara simultan

$\mathrm{H}_{\mathrm{a}}$ : Produk Wisata dan Kebijakan Harga berpengaruh signifikan terhadap Minat Wisatawan secara simultan

Pemilihan tempat rekreasi yang cendrung ke alam yang jauh dari polusi dan kebisingan, menjadikan wisata alam sebagai pilihan wisatawan untuk berlibur. Hal ini pun yang menimbulkan persaingan wisata khususnya di Kota Bogor dalam mengembangkan objek wisata masingmasing.Salah satu obyek wisata di Kota Bogor dengan ciri khas wisata agronya yaitu Taman Buah Mekarsari, yang merupakan salah satu pusat pelestarian keanekaragaman hayati buah-buahan tropika, khususnya buahbuah unggulan yang dikumpulkan dari seluruh daerah di indonesia.

Perkembangan objek wisata agro sejenis Taman Buah Mekarsari sekarang sudah banyak, oleh sebab itu perusahaan harus mampu menarik minat wisatawan untuk berkunjung dengan mengetahui apa yang diinginkan dan dibutuhkan oleh wisatawan supaya tertarik dan berminat untuk berwisata. Pada penelitian ini pada dasarnya adalah untuk mengetahui pengaruh produk wisata dan kebijakan harga terhadap minat wisatawan di Taman Buah Mekarsari Bogor.

Namun peneliti juga menganalisis tentang analisis deskripsi dari variabel produk wisata $\left(\mathrm{X}_{1}\right)$, kebijakan harga $\left(\mathrm{X}_{2}\right)$, dan minat wisatawan (Y). Selain itu peneliti melakukan pengujian secara parsial dari setiap variabel independen yaitu variabel produk wisata $\left(\mathrm{X}_{1}\right)$ dan kebijakan harga $\left(\mathrm{X}_{2}\right)$ terhadap variabel dependen yaitu minat wisatawan (Y).

Dalam penelitian ini menunjukan bahwa produk wisata yang ditawarkan oleh Taman Buah Mekarsari Bogor sudah baik dan mampu menarik minat wisatawan, hal ini di tunjukan dengan banyaknya tanggapan responden yang tinggi karena wisatawan menginginkan produk wisata yang sesuai dengan harapan wisatawan. Kesesuain tersebut diharapkan dari produk wisata yang menarik dan inovatif, produk wisata di Taman Buah Mekarsari Bogor sudah sesuai dengan harapan wisatawan dari banyaknya pilihan wahana wisata rekreasi dan edukatif serta wisata-wisata baru.

Produk wisata yang telah berkembang akan mampu meningkatkan jumlah kunjungan wisatawan yang nantinya bermuara pada pemberian manfaat ekonomi dengan menjalankan peran perusahaan agar produk wisata yang ditawarkan banyak diminati wisatawan dan terus berkembang pesat.

Hal ini didukung oleh teori pendapat (Gamal, 2007) yang mengemukakan "Pada hakikatnya produk wisata adalah keseluruhan pelayanan yang di peroleh dan di rasakan atau dinikmati wisatawan semenjak ia meninggalkan tempat tinggalnya sampai ke daerah tujuan wisata yang dipilihnya dan sampai kembali ke rumah dimana ia berangkat".

Kesesuain tersebut juga diharapkan dari harapan wisatawan supaya perusahaan dapat memberikan produk wisata yang terbaik agar wisatawan merasa puas dan dapat berkunjung kembali ke Taman Buah Mekarsari Bogor. Hal ini sesuai dengan teori yang dikatakan oleh (Alma, 2014) bahwa produk adalah segala sesuatu yang dapat ditawarkan dipasar, untuk memuaskan kebutuhan dan keinginan konsumen, produk terdiri dari barang, jasa, pengalaman, event, tempat, kepemilikan, organisasi, informasi dan ide.

Hasil analisis terhadap kebijakan harga yang ditetapkan oleh Taman Buah Mekarsari Bogor dinyatakan penting karena wisatawan menginginkan harga yang sesuai dengan harapannya. Kesesuain tersebut diharapkan dari harga produk di Taman Buah Mekarsari Bogor sudah sesuai dengan harapan dan keinginan wisatawan.

Hal ini juga sudah diperkirakan oleh perusahaan bahwa wisatawan akan mempertimbangkan harga sebelum membeli produk wisata yang di dukung oleh (Tjiptono, 2008) mengenai faktor yang mempengaruhi penetapan harga yaitu 
"persepsi konsumen terhadap harga dan nilai, ketika menetapkan harga perusahaan harus mempertimbangkan persepsi harga konsumen dan bagaimana persepsi ini mempengaruhi keputusan pembelian konsumen dan harga dan pesaing, jika suatu perusahaan mengetahui harga dan penawaran pesaing, perusahaan tersebut dapat menggunakannya sebagai penimbangan dalam penetapan harganya sendiri. Jika penawaran perusahaan sama dengan pesaing utamanya, perusahaan harus menetapkan harga terdekat dengan harga pesaing atau ia akan kehilangan order penjualannya".

Hasil tanggapan responden terhadap minat wisatawan ke Taman Buah Mekarsari Bogor, mendapatkan respon tinggi yang positif dan signifikan. Pada dasarnya sebelum berkunjung dan membeli suatu produk wisata, wisatawan melalui tahap awal yaitu perhatian (Attention) dimana produk wisata tersebut telah menarik perhatian calon wisatawan dan timbul ketertarikan (Interest) dimana seseorang memiliki perasaan ingin tahu lebih dalam tentang sesuatu hal yang jadi daya tarik sehingga muncul kemauan (Desire) yang muncul dari hati tentang sesuatu yang menarik perhatian dan melakukan sesuatu hal yaitu dengan sebuah tindakan (Action) dimana wisatawan pada akhirnya memutuskan untuk berkunjung ke objek wisata Taman Buah Mekarsari Bogor.

Secara umum prilaku konsumen dapatditunjukan bahwa dalam melakukan pembelian konsumen akan memilih jenis produk wisata yang ditawarkan, harga yang sesuai dengan fungsi produk dan manfaat yang baik sesuai dengan harga yang ditawarkan dan wisatawan pada akhirnya mendapatkan kepuasan.

Hal ini didukung dengan teori (Djaali., 2013) menyatakan bahwa "minat adalah rasa lebih suka atau rasa ketertarikan pada suatu hal atau aktifitas, tanpa ada yang menyuruh". Berdasarkan hal tersebut maka dapat di ambil kesimpulan bahwa produk wisata memiliki keterkaitan dalam menarik minat wisatawan dan harga yang terdapat pada produk wisata yang ditawarkan akan berpengaruh terhadap keinginan/minat wisatawan dalam berkunjung ke objek wisata tersebut, karena faktor harga merupakan salah satu hal yang dipertimbangkan wisatwan dalam berkunjung.

\section{SIMPULAN}

Dari hasil penelitian tentang produk wisata dan kebijakan harga terhadap minat kunjungan wisatawan Taman Buah Mekarsari Bogor ini, maka dapat diambil beberapa kesimpulan.

Produk Wisata di Taman Buah Mekarsari Bogor tercapai dengan skor total 3.808 (skor ideal 5.000) dengan tingkat persentase sebesar 76,2\%.Berdasarkan interval skor, skor total variabel produk wisata sebesar 3.808 berada pada interval 3.400-4200 dan termasuk kedalam kategori "Baik". Artinya, produk wisata diTaman Buah Mekarsari ditanggap "Baik" oleh responden.

Kebijakan Harga di Taman Buah Mekarsari Bogor tercapai dengan skor total 2.899 (skor ideal 4.000) dan dengan tingkat persentase sebesar 72.5\%. Berdasarkan interval skor, skor total variabel kebijakan harga sebesar 2.899 berada pada interval 2.720-3.360 dan termasuk kedalam kategori "Baik". Artinya, kebijakan harga diTaman Buah Mekarsari Bogor ditanggapi "Baik" oleh responden.

Minat Wisatawan di Taman Buah Mekarsari Bogor tercapai dengan skor total 3.170 (skor ideal 4.000) dan dengan tingkat persentase sebesar $77,7 \%$. Berdasarkan interval skor, skor total minat wisatwan sebesar 3.170 beradapada interval 2.7203.360 dan termasuk kedalam kategori "Baik". Artinya, minat wisatwan di Taman Buah Mekarsari Bogor ditanggapi "Baik" oleh responden.

Berdasarkan hasil hitung regresi linear berganda diperoleh bahwa variabel produk wisata $\left(\mathrm{X}_{1}\right)$ memiliki koefisien regresi sebesar 0,275 (bertanda positif) terhadap minat wisatwan(Y). Dan untuk hasil pengujian uji parsial (uji $\mathrm{T}$ ) diperoleh nilai $\mathrm{t}$ Hitung < t Table yaitu sebesar 4,282< 1.6671 
dengan tingkat signifikan 0,000 . Hal ini berarti bahwa produk wisata $\left(\mathrm{X}_{1}\right)$ berpengaruh positif terhadap minat wisatawan. Sesuai dengan hipotesis yang menyatakan bahwa terdapat pengaruh produk wisata terhadap minat wisatawan di Taman Buah Mekarsari Bogor. Maka hipotesis $\mathrm{H}_{1}$ diterima.

Berdasarkan hasil hitung regresi linier berganda diperoleh bahwa variabel kebijakan harga $\left(\mathrm{X}_{2}\right)$ memiliki koefisien regresi sebesar 0,663(bertanda positif) terhadap minat wisatawan (Y). Dan untuk hasil pengujian uji parsial (uji $\mathrm{T}$ ) diperoleh nilai $\mathrm{t}$ Hitung $>\mathrm{t}$ Table yaitu sebesar 10,320>1.6671 dengan tingkat signifikan 0,000 . Hal ini berarti bahwa kebijakan harga $\left(\mathrm{X}_{2}\right)$ berpengaruh positif terhadap minat wisatawan. Sesuai dengan hipotesis yang menyatakan bahwa terdapat pengaruh kebijakan harga terhadap minat wisatawan di Taman Buah Mekarsari Bogor. Maka hipotesis $\mathrm{H}_{2}$ diterima.

Berdasarkan hasil hitung uji koefisien determinasi $\left(\mathrm{R}^{2}\right)$ diperoleh bahwa koefisien determinasi $\left(\mathrm{R}^{2}\right)$ yang diperoleh sebesar 0,688 hal ini berarti $68,8 \%$ minat wisatawan dapat dipengaruhi oleh produk wisata dan kebijakan harga dan sisanya 31,2\% dipengaruhi oleh variabel-variabel lain yang tidak di jelaskan dalam model regresi ini. Dan berdasarkan hasil uji simultan di Taman Buah Mekarsari Bogor (uji F) diperoleh bahwa nilai F hitung sebesar 106,790 Dengan signifikansi 0,000. Dengan menggunakan batas signifikansi 0,05 diperoleh $\mathrm{F}$ tabel sebesar 3,09 artinya, F hitung > F tabel dan signifikansi hitung $<\alpha$. Sesuai dengan hipotesis yang menyatakan bahwa terdapat pengaruh produk wisata dan kebijakan harga terhadap minat wisatawan di Taman Buah Mekarsari Bogor. Maka hipotesis $\mathrm{H}_{3}$ diterima.

Indikator Produk Wisata yang memiliki skor terendah adalah tentang Taman Buah Mekarsari Bogor memiliki wisata buah yang menarik. Dalam hal ini Taman Buah Mekarsari disarankan lebih bnyak mengembangkan ragam buahannya, kemudia harus lebih di perhatikan perkembangan buahnya supaya dapat panen tepat waktu supaya dan meningkatkan minat wisatawan Taman Buah Mekarsari.

Indikator Kebijakan Harga yang memiliki skor terendah adalah potongan harga. Dalam hal ini Taman Buah Mekarsari Bogor disarankan supaya dapat lebih sering memberikan potongan harga pada hari-hari besar terutama ulang tahun Taman Buah Mekarsari Bogor supaya wisatawan tertarik dan berminat untuk berwisata.

Indikator Minat Wisatawan yang memiliki skor terendah adalah tentang koleksi buah-buahan yang di miliki Taman Buah Mekarsari Bogor. Dalam hal ini Taman Buah Mekarsari Bogor disarankan untuk lebih mengembangkan dan menambah koleksi buah-buahan lokal maupun mancanegara, selain itu juga buah-buah langka dari berbagai negara, supaya wisatawan lebih berminat berwisata.

Produk wisata di Taman Buah Mekarsari Bogor sudah sesuai dengan apa yang diinginkan wisatawan. Namun tetap perlu memperhatikan produk wisata yang ada, karena dengan produk wisata yang baik akan selalu dikenal dan dikenang oleh wisatawan y. Produk wisata juga merupakan salah satu faktor yang sangat mempengaruhi minat wisatawan. Salah satu carauntuk mempertahankan produk wisata yaitu dengan inovasi produk wisata secara berkala tanpa menghilangkan ciri khasnya.

Kebijakan harga yang ditawarkan Taman Buah Mekarsari Bogor sudah sesuai dengan apa yang diharapkan oleh wisatawan, namun masih ada sebagian kecil wisatawan yang tidak sesuai dengan harga yang ditawarkan. Apabila nanti harga akan dinaikan maka harus disertai dengan peningkatan produk wisata tersebut, supaya lebih mencangkup kesemua kalangan, dan penambahan produk dalam segi wahana. Walaupun segmentasi Taman Buah Mekarsari Bogor adalah kalangan menengah ke atas, tidak dipungkiri di kalangan menengah kebawah pun daya minatnya cukup tinggi, oleh sebab itu produk di sesuaikan dengan harga yang dapat terjangkau oleh semua kalangan dan juga memberikan potongan harga pada saat event 
tertentu yang akan meningkatkan minat wisatawan.

Penelitian selanjutnya disarankan untuk menambah variabel independen lainnya selain produk wisata dan kebijakan harga yaitu tentunya dapat mempengaruhi variabel dependen yaitu minat wisatawan agar lebih melengkapi penelitian ini. Karena masih ada variabel-variabel independen lain di luar penelitian ini yang mungkin mempengaruhiminat wisatawan.

\section{REFERENSI}

Alma, B. (2014). Manajemen Pemasaran dan Pemasaran Jasa. Bandung: Alfabeta.

Amalia. (2015). Pengaruh Kebijakan Penetapan Harga dan Kualitas Pelayanan Terhadap Proses Keputusan Pembelian Konsumen Baraya Travel. Universitas Widiatama.

Danang Sunyoto. (2013). Dasar-Dasar Manajemen Pemasaran. Yogyakarta: CAPS.

Djaali. (2013). Pisikologi Pendidikan. Jakarta: Bumi Aksara.

Fandy, T. (2011). Pemasaran Jasa. Malang: Bayumedia.

Gamal, S. (2007). Dasar-Dasar Pariwisata. Yogyakarta: ANDI.

Guspriyadi, E. (2015). Pengaruh Kualitas

Pelayanan Dan Produk Wisata Terhadap Minat Berkunjung Ke Kebun Binatang Bandung. STP ARS

INternasional.

Hermawan, H., Wijayanti, A., \& Nugroho, D. S. (2019). Loyalty on Ecotourism analysed using the factors of tourist attraction, safety, and amenities, with satisfaction as an intervening variable. African Journal of Hospitality, Tourism and Leisure, 8(5). Tersedia https://www.ajhtl.com/uploads/7/1/6/3/ 7163688/article 31_vol_8_5 2019_in donesia.pdf, diakses 1 November 2019.

Kamaludin, A. (2014). Pengaruh Bauran Pemasaran Produk, Harga Dan Lokasi Terhadap Keputusan Menginap Tamu Di Hotel Inna Simpang Surabaya (survey Kepada Wisatawan Tamu Menginap di Hotel Inna Simpang). Universitas Pendidikan Indonesia.

Koler, P., and Amstrong, G. (2012).

Principles of Marketing (14th ed.). New Jersey: Prentice Hall.

Kotler, Philip, . dan Kevin Lane Keller. (2009). Manajemen Pemasaran (13th ed.). Jakarta: Erlangga.

Kotler, P. and G. A. (2016). Prinsip-prinsip Pemasaran. Jakarta: Erlangga.

Kusumaningrum, D. (2009). Persepsi Pengunjung Nusantara Terhadap Daya TarikWisata Di Kota Palembang. Universitas Gadjah Mada.

Oka, A. Y. (2008). Pemasaran Pariwisata. Jakarta: PT Pradnya Paramitha.

Suryadana, M. Liga., dan V. O. (2015). Pengantar Pemasaran Pariwisata. Bandung: Alfabeta.

Tjiptono, F. (2008). Strategi Pemasaran. Yogyakarta: ANDI.

\section{PROFIL PENULIS}

Kartika Dewi, merupakan dosen ARS University, Bandung, Indonesia. Mengampu Mata Kuliah Pemasaran Pariwisata Email : kartikadewi31294@gmail.com 